УДК 821.111(73)-3.09

DOI https://doi.org/10.32999/ksu2663-3426/2020-2-12

\title{
MARK TWAIN AS A PROGRESSIVE WRITER: A STUDY OF WRITER'S STYLE
}

\author{
Aloshyna Maryna Dmytrivna, \\ Candidate of Philological Sciences, \\ Senior Lecturer at the Department of English Philology and Translation \\ Borys Grinchenko Kyiv University \\ m.aloshyna@kubg.edu.ua \\ orcid.org/0000-0003-2055-9920
}

\begin{abstract}
Mark Twain's figure is very contradictory as well as his creative work. His most famous works were banned and were censured but, after all, his works were recognized as embodiment of his unique individual style. Moreover, Mark Twain's innovative style was reproduced into different languages, thus, translators had to search for substandard approaches in order to reproduce its determinant features. The writer uses the language of American province, in particular south-western dialect, Missouri negro dialect and Pike Country dialect and its modifications, which are the cornerstones of approach in translation of his works. The language of characters has features of colloquialism, full of slang, idioms, and substandard tense forms, misspelled words, incomplete sentences, interjections etc. The individuality of each character and their territory belonging is shown through the combination of different dialects and the combination of high and low style. The writer performed literary revolution and created a new style of writing. Twain used different languages to make language vivid and realistic. Their skillful combination is the peculiarity of his style, which makes his books interesting and attractive for readers. Mark twain individualizes the language of his characters in order to show real life from all its aspects. Besides. Dialect shows territory belonging of his characters. With the help of dialects and their different forms Mark twain makes effects of irony and humor. The use of living people's lexicon combined with the use of different forms of dialects yields peculiarity to Mark Twain's individual style. Character's speech is marked with idioms, elliptic constructions, interjections. Besides, the writer used highly expressive words trying to show individuality of his characters through their speech. All this helped to reproduce pictures of people's life, manners and customs credibly. The analysis showed that invariant features of Mark twain's individual style are dialects, colloquialisms, phraseology and idioms. Other features that are typical for the writer are: interjections, tropes, repetitions and substandard grammar constructions.
\end{abstract}

Key words: individual features, writing style, dialect, slang, character's speech.

\section{МАРК ТВЕН - ПРОГРЕСИВНИЙ ПИСЬМЕННИК: ДОСЛІДЖЕННЯ ІДІОСТИЛЮ АВТОРА}

\author{
Альошина Марина Дмитрівна, \\ кандидат фолологічних наук, \\ старший викладач кафедри англійської фрілології та перекладу \\ Київський університет імені Бориса Грінченка \\ m.aloshyna@kubg.edu.ua \\ orcid.org/0000-0003-2055-9920
}

Марк Твен - дуже суперечлива постать так само, як і його творчість. Його найвідоміші книги були заборонені, та все ж їх визнали втіленням унікального індивідуального стилю автора. Крім того, новаторський стиль Марка Твена був переданий багатьма мовами, тому перекладачам довелося шукати нестандартні підходи до відтворення його визначних рис. Письменник послуговувався мовою американської провінції, зокрема південно-західним діалектом, діалектом негрів Міссурі та діалектом округу Пайк, та його модиффікації, які є наріжними каменями для пошуку підходів при перекладі його творів. Мова персонажів має особливості розмовної мови, наповненої жаргоном, ідіомами та нестандартними граматичними конструкціями, неправильно написаними словами, незавершеними реченнями, вставними словами тощо. Індивідуальність кожного персонажа та його територіальна приналежність демонструється через поєднання різних діалектів, високого і низького стилів. Письменник здійснив літературну революцію і створив новий стиль написання творів. Твен вживав різні діалекти, щоб зробити мову яскравою та реалістичною. Їх вміле поєднання - це особливість його стилю, що робить його книги цікавими та привабливими для читачів. Марк Твен індивідуалізує мову своїх героїв, щоб показати усі аспекти реального життя. За допомогою діалектів та їх різних форм Марк Твен досяг ефектів іронії та гумору. Використання просторічної лексики персонажів у поєднанні з різними формами діалектів дає особливість індивідуальному стилю Марка Твена. Мова персонажів позначена ідіомами, еліптичними конструкціями, вставними словами. Крім того, письменник вживав експресивну лексику, намагаючись показати індивідуальність своїх героїв через їхнє мовлення. Все це допомогло достовірно відтворити картини життя, звичок та звичаїв людей. Аналіз показав, що незмінними рисами індивідуального стилю Марка Твена є діалекти, просторіччя, фрразеологія та ідіоми. Іншими рисами, характерними для індивідуального стилю письменника, є: вставні слова, тропи, повторення та нестандартні граматичні конструкції.

Ключові слова: фрразеологія, індивідуальний стиль, визначні риси, діалект, мовлення персонажів. 
Introduction. Samuel Langhorne Clemens famous under the pseudonym Mark Twain had a great influence as a pioneer of new ways and opportunities, having defined a task to develop American literature. He became famous for such works as: Innocents abroad) (1869, Roughing it (1872) and Life on the Mississippi (1883), and also for his novels The Adventures of Tom Sawyer (1876), and Adventures of Huckleberry Finn (1885). Ernest Hemingway supposed that "all modern American literature appeared from Mark Twain's book Adventures of Huckleberry Finn. A lot of researches have been dedicated to the writer's biography and creative work. Despite hundred years have passed since the author's death he is still popular, his works are interesting and exciting.

Talking about the individual style of Mark Twain, it's important to note that he was consummate master of humour. But, gradually, friendly humour transformed into sharp satire. One can notice its universal character in Twain's late works. According to Frederik Henderson, Mark twain managed to create literary style, which reflects America, his conception of the world. Besides, he was the first who used dialect at the level of art (De Voto 1942, p. 27).

Chapter 1. It's important to note that a lot of diversions from literary norm in Mark Twain's novels reflects traditions in American literature of II half of XIX century: realism, regionalism, western frontier humor (Nemtsova 2011, p. 17). Besides, they are an important element of character's speech. First of all, grammatical diversions indicate on social belonging of character's. We pointed out about 400 grammatical diversions in the novel "The Adventures of Tom Sawyer" and about 3600 in the novel "The Adventures of Huckleberry Finn".

Evidently, the writer's style developed. We can point out gradual changes from humor to satire: irony and humor in "Innocents abroad" and "Roughing it", these works reflect frontier. During 1873 - 1878 economic crisis starts in the USA and it generates satire, which was reflected in "The Gilded age". The writer showed real life of American people of the time when politicians promised prosperity but Twain saw it as shameless greed, speculation and unrestricted corruption (Kubareva 2004, p. 94).

Remembrance of the past youth, which was in "The Adventures of Tom Sawyer", "Life of the Mississippi", "Adventures of Huckleberry Finn". During this period Mark Twain changes irony to satire and typical narration is replaced by social critics (Kubareva 2004, p. 99). Excursus to Middle Ages and romantic outburst of passion of Enlightenment in "The Prince and the Pauper", "The Connecticut Yankee in King Arthur's Court"; search for ideal and dream about ideal woman in "Personal Recollections of Joan of Arc"; and "Mysterious stranger", and "What is a man?" - sharp satire and disillusion (Parrington 1987, p. 91).

Thus, in his first book "The celebrated jumping frog from Calaveras country" 1867, which brought fame to its author, Mark Twain used 'abstruse' words and word combinations intentionally, he also used loanwords and barbarisms to deepen the contrast with narrator's speech. The writer broke grammar rules, the narrator spoke illiterately, without differentiating singular from plural, agreeing of grammar forms, using double negations. Note, that Twain used vocabulary of that time, which reflected social stratum (Nalyvaiko 2001, p. 93).

Generally, there are two main traditions of American literature in the writer's creative work: book and folk. Special features of American literature were embodied in Twain's prose, first and foremost, it metaphorical structure (Zasurskii 1981, p. 14). Similar to Brett Hart and Fennimore Cooper Twain was connected with frontier by his biography. He developed and modified the traditions of this region. His early works have features of spontaneity and improvisator's skills (Zasurskii 1981, p. 244). First, the writer targeted at plain people. Besides, the author based himself upon the traditions of early epochs, giving advantage to methods and stylistics of Cervantes, Shakespeare, Defoe, Voltaire and Dickens (Zasurskii 2003, p. 15).

What is more, in his "Autobiography", printed in November 2011, Mark Twain noted that he didn't have clear norms and rules of style. He didn't strive for following any literary movement or traditions. The contrasts of high and low styles, to his mind, had to excite interest to his books. The writer used dialect and their modifications to create new literary style. Twain strived for creating new form and method of writing. His works contain episodes from his own life experience. The author wanted to interest plain people in his works as they contain something very familiar to the reader, something they see their lives in. Furthermore, Clemens tried to show real language, which was used by the Americans at that time. He wanted people read his books during centuries.

Usage of high and low style is typical American humor even in its rudest forms (Loving 2010, p. 2). According to J.Loving, evident 
difference between "high" and "low" styles is in his character's speech and the use of local dialects was one of the easiest sources of humor (Loving 2010, p. 4).

The use of living people's lexicon combined with the use of different forms of dialects yields peculiarity to Mark Twain's individual style. Character's speech is marked with idioms, elliptic constructions, interjections. Besides, the writer used highly expressive words trying to show individuality of his characters through their speech. All this helped to reproduce pictures of people's life, manners and customs credibly.

Chapter 2. We can point out such dominant features in the writer's individual style as dialecticism and idiomatic expressions. Note that Mark Twain used Pike country dialect and its four modifications, Missouri Negro dialect and southwestern dialect in his famous novels "The Adventures of tom Sawyer" and "Adventures of Huckleberry Finn". Moreover, Pike Country was founded in 1818 and included a great territory in Missouri. When twain was young his native city belonged to Pike Country (Menchen 1964, p. 464). The language of citizens of this territory was far from standards, later it was named General English (Buxbaum 1927, p. 233). It was considered that these inhabitants had low level of education, were rude and ignorant. Speech peculiarities reflected their way of life and social status. Eventually, any type of wrong and substandard language as citizens couldn't distinguish this type of dialect from others (Buxbaum 1927, p. 236). In the aspect of individual style research there's still a problem of the quantity of used dialects in the novels "The Adventures of tom Sawyer" and "Adventures of Huckleberry Finn".

Besides, not all researchers point out seven dialects in these novels. According to C.M.Rulon distinguished only two: afro American dialect and dialect of Americans of European origin (Rulon 1971). Such scholars as V.Brekenridge, V.Rondolf, J.Wilson, S.Boland support this opinion. D.Carkeet in his research compared dialect peculiarities with their use in character's speech (Carkeet 1979). The researcher took Huck's speech, who spoke Pike Country dialect, as a basis, compared with the speech of other character's and pointed out its main peculiarities. Nevertheless, D.Carkeet says that the difference between dialects is insignificant as it means the use of more or less quantity of substandard language forms (Carkeet 1979, p. 315).

L.Pederson did sociolinguistic analysis and managed to find correspondences between speech peculiarities of Jim and afro Ameri- cans, who lived in Missouri state (Pederson 1962, p. 261). Evidently, Jim's speech is different from other character's speech at phonetic level. Grammatical peculiarities aren't different from other dialects used in novels. Afro American dialect is the dialect of the lowest, the most miserable stratum of American population of that time.

Besides, the author also used colloquial speech and popular language. In "Adventures of Huckleberry Finn" Twain organized into big structure those facts that early humorists wrote in short anecdotes. H.N.Smith points out that Mark Twain's development as a writer is dialectical interaction, innovative methods opened new perspectives for Mark Twain. Concentration on Huckleberry opened new possibilities for the use of dialects for serious purposes(Smith 1962, p. 113).

What is more, Twain's intention as an artist of life truth required courage and bravery as he violated literary norms impertinencetly. Mark Twain's innovative novel caused boisterous polemics after its publication. Supporters of refined literature, who demanded irreproachable content, irreproachable protagonist and "good manners", they marked the book as "indecent, vulgar, rude".

The journal "Century", which published extracts of "Adventures of Huckleberry Finn" before publication, insisted on deleting references on naked body, dead cats etc. That's why, the writer created his own publishing house in order to publish the novel. Besides, public libraries removed the book from its shelves as "rubbish suitable only for dump", commenting that the series of adventures has low level of morality, rude dialect, systematic use of bad grammar and impolites words, generally, the style of the book is impudent and irreverent (Kaplan 1985, p. 11).

Half a century ago in 1931 publishing house Harper and Brothers published special issues for primary and secondary school. Publishers noted that cut version with deletion of "doubtful parts will give Huck an opportunity to stand on bookshelves and enter classrooms", thus providing "boys and girls' happiness" and stimulating "even more indifferent and capricious pupils". In 1957 Department of Education of New York removed the novel from the list of approved texts (Kaplan 1985, p. 14). Besides, many readers acknowledged Twain's novel as unacceptable because of violation of refined standards of social and literary etiquette, instead of refined language, model hero, high morality, they faced with narration, written with idioms by illiterate 
boy from the lowest stratum of southern white society. Besides, Hucks story included indecent scene - "king's model", which described naked man, who humps to all sides (Kaplan 1985, p. 16).

After successful war with racist segregation, starting from the second half of XX century, new reasons for accusations appeared. Thus, in 1957 the novel was censured as "racist offensive" and in 1984 it was removed from the list of obligatory reading at school because of the use of the word "nigger" (Kaplan 1985, p. 18). Hence, at general national level the demand to remove the book from the list of works, which are obligatory for reading, was declined at federal court in 1998.

Note that in February 2011 in the USA there appeared first edition of the book where "offensive" words were replaced with "polite" ones, in particular the word "nigger" was changed into "slave". As Associated Press informs the book was edited in 7500 copies. Publishing house «New South Books» (Alabama) prepared this edition. Generally, there are 219 words, which are offensive for Afro-Americans (according to the present standards) in the novel "Adventures of Huckleberry Finn", in "The Adventures of Tom Sawyer" only 4. This calculation was done by Allan Gribben. According to him, during public reading he uses 'neutral' words instead of original words and the public likes it.

What is more, "Huckleberrry Finn" is not persecuted for the first time and takes the $4^{\text {th }}$ place of the most often banned at American schools. Opponents of deformation of Mark Twain's texts, they emphasize that his creative work reflects the definite stage of American history and it was more reasonable just to explain the reader why some word combinations were used. Despite bans, "The Adventures of Huckleberry Finn" became best seller. The book was read in almost all languages of civilized world. H.L.Menken named the novel as the most unusual book, T.S.Elliot noted that Mark Twain is one of rere authors who modernized his language and found new way of writing, which was important not only for him but also for others (Kaplan 1985, p. 13). According to J.Kaplan, Twain performed cultural and literary revolution, having used dialect (Kaplan 1985). Paul Nidman noticed: "What you see is Clemens' attempt to diverge from literary writing to dialectical".

Besides, Mark Twain returned to his favorite form of narration from the first person and made Huck his protagonist, not Tom. It had double effect. First of all, language was skillfully reproduced, strong and vivid, truly people's language ads special expressiveness, created conversations without mediator as if America talked in its own voice. Secondly, it let to show the protagonist's character more fully and deeply, show the development of his personality (Romm 1977, p. 86).

Mark Twain notes in his Autobiography that a person, who knew Hannibal in 1840 will recognize Tom Blankenship easily, his father was a drunkard. The writer said that he showed Huck exactly as he was: ignorant, dirty, hungry, but he had kind heart. The image of Tom Blankenship personified the embodiment of freedom and knowledge about such important things as fishing, hunting, sorcery, what made his very important friend (Neider 1960, p. 397). According to S.Hutchinson, Clemens could embody the deepest sense of his life comedy and tragedy only behind the mask of Huckleberry Finn (Twain 2001).

Moreover, writers-realists perceived the novel as innovatory and highly artistic. J.Ch.Harris defined the meaning of the book as "It's life". The prose of "The Adventures of Huckleberry Finn" is based in order to make written prose of American colloquial speech effective.

According to L.Trilling Huckleberry Finn is almost ideal work as to its form and content. The form of the book is based on the simpliest form of the novel, so-called adventurous novel or the novel of roads, where the protagonist's adventures are connected with his travelling. The language of characters has nothing in common with normative pronunciation and grammar but it has simple and facile sentence structure (Inge 1985, p. 91). As the language of literature of that time was high, American readers were interested in reality of everyday language. Dialect attracted even serious writers, it was the basis of popular humorous works.

Thus, during the trip on Mississippi we see Huck and Jim with two frauds, who name themselves as miserable aristocrats. Huck dislikes their grimaces, his disgust is at peak when 'king' and 'duke' intend to rob three girls, hiding their intention behind family love and Christian sympathy. Huck is angry when 'king' acts like preacher and sad brother. Twain makes an effect of irony in the novel by the combination of styles, skilful mix of Huck and 'king's' voices makes highest satiric effect (Inge 1985, p. 202). Two Huck's favourite adjectives - 'sickening' and 'goody-goody'. When Huck writes 'king's' speech he borrows his 'pious' vocabulary intentionally (Inge 1985, p. 205). Huck considers 'king's' weeping and whimpering as disgusting nonsence. Note that phrasal verbs and vernacular syntactic constructions play an important role in Huck's style (Inge 1985, p. 204). Twain 
describes hypocritical devotion and sentimentality of pre-war South. Ambiguity is typical feature of Huck's style.

Besides, in "The Adventures of Huckleberry Finn" main disadvantage of Twain's technique was avoided - compositional insufficiency, which he used when he was a reporter. Almost all writer's books have free composition, close to associative thinking. In "The Adventures of huckleberry Finn" this disadvantage became a bright advantage. It became fundamental for author's intention: free composition of the novel corresponds very important image of big river. According to J.Seelye, the best feature of the novel is Twain's ability to persuade (Seelye 2002, p. 28).

R.Chase notes, that this book attracts the reader by its language. Twain's language is the style, which flows easily as colloquial speech and reaches pureness and simplicity avoiding subordinate clauses (Chase 1978, p. 139). Huck's language is new literary style, which is one of the means of realism. L.Trilling determines the ability to tell truth as the peculiarity of the novel (Chase 1978, p. 143). The change of tension together with the change of language, sudden change from traditional English to colloquial American language also attract readers (Chase 1978, p. 140).

To sum up, we can structure main features of mark twain's individual style as follows:

- $\quad$ at phonetic level:

- shortening: foolin','roun', an', 'em, 'nuffn, 'long;

- the use of th instead of «d»: dis, dey, wid;

- assimilation: warn't, tole, afeard.

At morphological level we can point out such peculiarities as:

- the use of particle «a» at the beginning of the word: a-laying, a-swimming, a-going, a-shaking, a-fishing;

- substandard use of the verbs «to be» and «have»: ain't, hain't;

- formation of past tense of verbs with the help of «-ed»: knowed.

Lexical level of the writer's style is represented by:

- dialects: 'Lord, pap can tell, easy. Pap says when they keep looking at you right stiddy, they're a-witching you, specially if they mumble. Becuz when they mumble they're a-saying the Lord's Prayer backards.'

- slang: 'I dunno. But they've got to do it. Hermits always do. You'd have to do that if you was a hermit.'

- phraseology: God knows, the Lord's truth, to turn tail, to take a walk, to be full of the Old Scratch, to know where the wind lays.
- idioms: 'Shut your heads and let Tom go on! What did he say, Tom?'

- tropes: 'Tom, what on earth ails that cat?'

At grammatical level we can point out:

- mistakes in word order in the sentence: Thinks I, what is the country a-coming to?

- Inconsistency of subject and predicate: there orter be, there was ways, I says, it don't hurt any more;

- The use of past form instead of past participle: they've all forgot. He had a gun which he had stole.

- The use of double negation: I don't take no stock. The injun blood ain't in me for nothing.

At syntactic level Mark Twain's individual style is characterised by:

- Incomplete sentences: 'I forgive everybody, Sid. Tell 'em so, Sid, you give my window-sash and my cat with one eye to that new girl that's come to town, and tell her - '

- eliptic constructions: We never seen any marks at all.

The analysis showed that invariant features of Mark twain's individual style are dialects, colloquialisms, phraseology and idioms. Other features that are typical for the writer are: interjections, tropes, repetitions and substandard grammar constructions.

Thus, Twain used different languages to make language vivid and realistic. Their skillful combination is the peculiarity of his style, which makes his books interesting and attractive for readers. Mark twain individualizes the language of his characters in order to show real life from all its aspects. Besides. Dialect shows territory belonging of his characters. With the help of dialects and their different forms Mark twain makes effects of irony and humor.

\section{ЛІТЕРАТУРА:}

1. История зарубежной литературы конца XIX нач. XX вв. / [ред. М.Е.Елизарова, Н.П. Михальской]. М. : Высшая школа, 1970. 620 с.

2. История литературы США. Литература последней трети XIX века 1865 - 1900 (становление реализма) / [ред. Я.Н. Засурский]. М.: ИМЛИ РАН, 2003. Т. 4. 992 с.

3. Кубарева Н.П. Зарубежная литература последняя треть XIX начало XX вв. М.: Московский лицей, 2004. 344 c.

4. Наливайко Д.С. Зарубіжна література XIX сторіччя. Доба романтизму. Тернопіль: Богдан, 2001. 416

5. Немцова Н.В. Проблема эквивалентности и адекватности при переводе грамматических отклонений от нормы. Вестник МГОУ. Серия: Лингвистика. 2011. № 3. C. 178-185.

6. Проблемы становлення американской литературы / [ред. Я.Н.Засурский]. М.: Наука, 1981. 384 с. 
7. Ромм А.С. Марк Твен и его книги о детях. М.: Наука, 1977. 192 c.

8. У США видадуть “кастровану" версію книг Марка Твена. URL: http://kievpapa.livejournal.com/2985.html.

9. Buxbaum, K. Mark Twain and American Dialect // American speech, № 5. 1927. P. 233-236.

10. Carkeet, D. The Dialects in Huckleberry Finn. American Speech, № 3. 1979. P. 315.

11. Inge, T. M. Huck Finn among the Critics: a centennial selection. Maryland : University publications of America, 1985. $465 \mathrm{p}$.

12. Jerome Loving Mark Twain: The Adventures of Samue L. Clemens. Berkeley: University of California Press, 2010. $491 \mathrm{p}$.

13. Kaplan, J. Born to trouble. 100 years of Huckleberry Fin. Washington: Library of Congress, 1985. 23 p.

14. Mark Twain The adventures of Tom Sawyer. The adventures of Huckleberry Finn. London : Wordsworth classics, 2001. $396 \mathrm{p}$.

15. Mark Twain. The adventures of Huckleberry Finn; [ed. by J.Seelye]. N.Y. : Penguin classics, 2002. 368 p.

16. Mencken, H.L. The American Language. N.Y : Citadel Press, 1964. $777 \mathrm{p}$.

17. Parrington, V. L. Main Currents in American thought. The beginning of critical realism in America, 1860 - 1920. Norman: University of Oklahoma press, V.III. 1987. 429 p.

18. Pederson, L.A. Mark Twain's Missouri Dialects: Marion County Phonemics. American Speech, № 4. 1962. P. 261.

19. Richard, C. The American novel and its tradition. N.Y. Gordian press, 1978. 266 p.

20. Rulon, C.M. Geographical delimitation of the dialect areas in The Adventures of Huckleberry Finn. A various language: Perspectives on American dialects. N.Y, 1971. P. 215-221.

21. Smith, H. N. Mark Twain. The development of a writer. Cambridge: Belknap Press of Harvard University Press, 1962. $212 \mathrm{p}$.

22. The Autobiography of Mark Twain: including chapters now published for the first time [ed. Ch.Neider]. N.Y. : Harper and Row, 1960. $388 \mathrm{p}$.

23. Voto, de B. Mark Twain at. Cambridge: Harvard University Press, 1942. 144 p.

\section{REFERENCES:}

1. Buxbaum, K. (1927). Mark Twain and American Dialect // American speech, № 5. P. 233-236.

2. Carkeet, D. (1979). The Dialects in Huckleberry Finn [American Speech], № 3. P. 315.

3. Chase, R. (1978). The American novel and its tradition. N.Y. : Gordian press, 266 p.

4. Inge, T. (1985). Huck Finn among the Critics: a centennia selection. - Maryland : University publications of America, $465 \mathrm{p}$.

5. Istoriia literatury SShA. Literatura posledniei treti XIX veka 1865 - 1900 (stanovlenia realizma) [The history of the literature of the USA. The literature of the last decade of the XIX th century 1865-1900 (the history of Realism)]. M.: IMLI RAN, 2003. V. 4. 992 p.
6. Istoriia zarubezhnoi literatury kontsa XIX nachala XX vV. [The history of foreign literature of the end of the $X I X^{\text {st }}$ - beginning of the $X X^{\text {th }}$ centuries]. M.: Vysshaia shkola, 1970. $620 \mathrm{p}$.

7. Jerome Loving (2010). Mark Twain: The Adventures of Samuel L. Clemens. Berkeley: University of California Press, $491 \mathrm{p}$.

8. Kaplan, J. (1985). Born to trouble. 100 years of Huckleberry Fin. Washington : Library of Congress, 23 p.

9. Kubareva, N.P. (2004). Zarubezhnaia literature posledniaia tret $\mathrm{XIX}$ nachalo $\mathrm{XX}$ vV. [Foreign literature of the last decade of the $X I X^{\text {th }}$-beginning of the $X X^{\text {th }}$ centuries] M.: Moskovskii litsei, 2004. $344 \mathrm{p}$.

10. Mark Twain (2001). The adventures of Tom Sawyer. The adventures of Huckleberry Finn. London : Wordsworth classics, $396 \mathrm{p}$.

11. Mark Twain (2002). The adventures of Huckleberry Finn; [ed. by J.Seelye]. N.Y. : Penguin classics, 368 p.

12. Mencken, H.L. (1964). The American Language. N.Y : Citadel Press, $777 \mathrm{p}$.

13. Nalyvaiko, D.S. (2001). Zarubizhna literature XIX storichchya. Doba romantyzmu [Foreign literature of the XIX century. The epoch of Romanticism]. Ternopil: Bohdan, 2001. $416 \mathrm{p}$.

14. Nemtsova, V.V. Problema adekvatnosti I ekvivalentnosti pri perevode grammaticheskikh otklonenii ot normy [The problems of adequacy and equivalence in grammatical deviation]. Vesnik MGO: Lingvistika, 2011. № 3. P. 178-185.

15. Parrington, V.L. (1987). Main Currents in American thought. The beginning of critical realism in America, 1860 - 1920. Norman : University of Oklahoma press, V.III. 429 p.

16. Pederson, L.A. (1962) Mark Twain's Missouri Dialects: Marion County Phonemics [American Speech], № 4. P. 261.

17. Problemy stanovlenia amerikanskoi literatury [The problems of the development of the American literature]. M: Nauka, 1981. 384 p.

18. Romm, A.S. (1977). Mark Twen I ego knigi o detiakh. [M. Twain and his books about children]. M: Nauka, $192 \mathrm{p}$.

19. Rulon, C.M. (1971). Geographical delimitation of the dialect areas in The Adventures of Huckleberry Finn [A various language : Perspectives on American dialects]. N.Y, P.215-221.

20. Smith, H.N. (1962). Mark Twain. The development of a writer. Cambridge : Belknap Press of Harvard University Press, $212 \mathrm{p}$.

21. The Autobiography of Mark Twain: including chapters now published for the first time (1960) [ed. Ch.Neider]. N.Y. : Harper and Row, 388 p.

22. U SShA vydadut kastrovanu versiiu knyg Marka Twena [The USA is going to publish a "castrated" version of M. Twain's books]. URL: http://kievpapa.livejournal. com/2985.html.

23. Voto, de B. (1942). Mark Twain at. Cambridge : Harvard University Press, 144 p.

Стаття надійшла до редакиії 13.10.2020. The article was received October 13, 2020. 